\title{
ORIGINAL ARTICLE \\ The mechanisms of wine phenolic compounds for preclinical anticancer therapeutics
}

\author{
Jing Duan', Hua Guo², Yulin Fang ${ }^{1 *}$ and Guangbiao Zhou²* \\ 'College of Enology, Northwest A\&F University, Yangling, China; ${ }^{2}$ State Key Laboratory of Molecular Oncology, \\ National Cancer Center/National Clinical Research Center for Cancer/Cancer Hospital, Chinese Academy of Medical \\ Sciences and Peking Union Medical College, Beijing, China
}

\section{Popular scientific summary}

- Wine phenolic compounds have an important impact on human health.

- Wine phenolic compounds may act against cancers via modulating multiple biological mechanisms.

- The relationship between wine consumption and health still remains controversy.

\section{Abstract}

Background: Wine is one of the oldest and most popular drinks worldwide, which is rich in phenolic compounds. Epidemiological studies show that moderate consumption of wine can reduce the risk of certain diseases, and this effect is attributed to its phenolic compounds.

Objective: The objective of this review was to elaborate the effects of wine-derived phenolic compounds for preclinical anticancer therapeutics and their major mechanisms.

Methods: In this review, we discuss the classification and content of common phenolic compounds in wine and summarize previous studies that have evaluated the anticancer properties of wine-derived phenolic compounds and their mechanisms.

Results: Wine-derived phenolic compounds have been proven to participate in several mechanisms against cancers, including deoxyribonucleic acid damage, oxidative stress, cell proliferation, cell cycle arrest, cell apoptosis, autophagy, cell invasion and metastasis, immunity and metabolism, regulation of multiple signaling molecules, and gene expression. However, the exact anticancer mechanisms of the phenolic compounds in wine need to be further investigated.

Conclusion: Wine-derived phenolic compounds are promising chemoprotective and chemotherapeutic agents for cancer.

Keywords: wine; cancer; phenolic compounds; mechanism; chemotherapy

$\mathrm{W}$ ine is an alcoholic beverage obtained from the fermentation of the juice of freshly gathered grapes. The composition of wine is significantly different from that of grape juice. One of the reasons could be ascribed to the fact that some components of grapes are discarded during winemaking. Another reason could be attributed to the complicated series of transformations and processes related to winemaking, which affect the final product. Red wine, especially, is a rich source of phenols and represents an important dietary ingredient for human consumption (1). The main phenolic compounds found in wine are flavonoids and non-flavonoids. The most common flavonoids in red wine are flavonols, flavanols, and anthocyanins, while the commonly occurring non-flavonoids are mainly derivatives of hydroxycinnamic and hydroxybenzoic acids, hydrolyzable tannins, and stilbene (2), as shown in Table 1. The chemical structures of the phenolic compounds frequently found in wine are shown in Fig. 1.

Currently, the treatment modalities for cancer include surgery, immunotherapy, radiation therapy, targeted therapy, and chemotherapy. The two most important factors considered during chemotherapy are the dose and toxicity of the drug. Many naturally occurring phenols are efficacious at low doses and are not associated with significant toxicities. Epidemiological and clinical studies show that 
Table 1. The main phenolic compounds in red wine

\begin{tabular}{|c|c|c|c|}
\hline Basic type & Concentration & $\begin{array}{l}\text { Common } \\
\text { component }\end{array}$ & Reference \\
\hline \multirow[t]{3}{*}{ Flavonols } & $50-200 \mathrm{mg} / \mathrm{L}$ & Quercetin & $(3,4)$ \\
\hline & & Kaempferol & \\
\hline & & Myricetin & \\
\hline \multirow[t]{5}{*}{ Flavanols } & $40-120 \mathrm{mg} / \mathrm{L}$ & Catechin & $(3,5,6)$ \\
\hline & & Epicatechin & \\
\hline & & Epigallocatechin & \\
\hline & & Epicatechin gallate & \\
\hline & $500-1,500 \mathrm{mg} / \mathrm{L}$ & Proanthocyanidins & \\
\hline \multirow[t]{5}{*}{ Anthocyanins } & $90-400 \mathrm{mg} / \mathrm{L}$ & Cyanidin & $(3,7)$ \\
\hline & & Delphinidin & \\
\hline & & Peonidin & \\
\hline & & Malvidin & \\
\hline & & Petunidin & \\
\hline \multirow{6}{*}{$\begin{array}{l}\text { Hydroxycinnamic } \\
\text { acids and } \\
\text { hydroxybenzoic } \\
\text { acids }\end{array}$} & $60-240 \mathrm{mg} / \mathrm{L}$ & Caffeic acid & $(3,8)$ \\
\hline & & Ferulic acid & \\
\hline & & Chlorogenic acid & \\
\hline & & Gallic acid & \\
\hline & & Vanillic acid & \\
\hline & & Coumalic acid & \\
\hline \multirow{2}{*}{$\begin{array}{l}\text { Hydrolyzable } \\
\text { tannins }\end{array}$} & $0-260 \mathrm{mg} / \mathrm{L}$ & Ellagitannins & $(3,9)$ \\
\hline & & Gallotannins & \\
\hline Stilbene & $0-7 \mathrm{mg} / \mathrm{L}$ & Resveratrol & (10) \\
\hline
\end{tabular}

moderate wine consumption has chemopreventive effects and also exhibits therapeutic effects in individuals with cardiovascular disease, hypertension, diabetes, and cancers (1). In 1997, Jang et al. (11) confirmed that phenols are the functional substances in wine. Since then, numerous studies have shown that the positive effects of wine on health are attributed to its polyphenolic compounds, as these compounds exhibit antioxidant, anti-inflammatory, hypotensive, anticoagulant, and even anticancer effects (12-14). The beneficial effects of these compounds in some diseases are related to the ability of phenolic compounds to scavenge reactive oxygen species (ROS), nitrogen radicals, and chlorine species $(15,16)$. However, the chemopreventions of certain diseases, especially cancers, are challenging as they are related to the interaction of proteins and involve complex cell signaling pathways (17, 18). In recent years, many phenolic compounds in wine have been proven to have prophylactic or therapeutic effects on various types of cancers, including cancers of the colon (19), ovary (20), breast (21), lung (22), and prostate gland (23).

The phenolic compounds in wine have been shown to have anticancer effects, and resveratrol is the most studied compound. The phenolic compounds in wine are known to play a role in inducing cell cycle arrest, apoptosis, autophagy, deoxyribonucleic acid (DNA) damage, and p53<smiles>O=c1c(O)c(-c2ccc(Cl)c(O)c2)oc2cc(O)cc(O)c12</smiles><smiles>Oc1cc(O)c2c(c1)OC(c1cc(O)c(O)c(O)c1)C[C@H]2O</smiles>

Epigallocatechin<smiles>OCC1OC(Oc2cc3c(O)cc(O)cc3cc2-c2cc(O)c(O)c(O)c2)C(O)C(O)C1O</smiles>

Malvidin-3-galactoside<smiles>O=C(O)C1=CC(O)C(O)C(O)C1</smiles>

Gallic acid<smiles>O=c1c(O)c(-c2ccc(O)cc2)oc2cc(O)cc(O)c12</smiles>

Kaempferol<smiles>O=C(O[C@H]1Cc2c(O)cc(O)cc2OC1C1C=C(O)C(O)CC1)c1cc(O)c(O)c(O)c1</smiles>

Epicatechin gallate

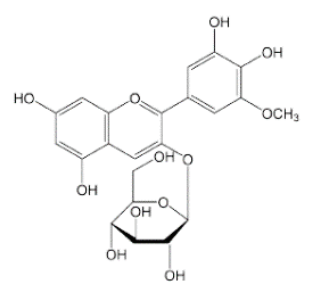

Petunidin 3-glucoside<smiles>O=C(O)c1ccc(O)c(O)c1</smiles>

Vanillic acid<smiles></smiles>

Myricetin

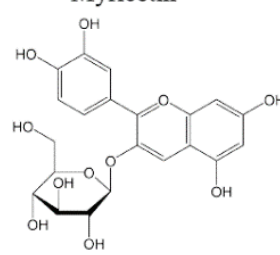

Cyanidin-3-glucoside<smiles>O=C(O)C=Cc1ccc(O)c(O)c1</smiles>

Caffeic acid<smiles>O=Cc1ccc(C(=O)O)cc1</smiles>

Coumalic acid<smiles>Oc1cc(O)c2c(c1)OC(c1ccc(O)c(O)c1)C(O)C2</smiles>

Catechin<smiles></smiles>

Delphinidin
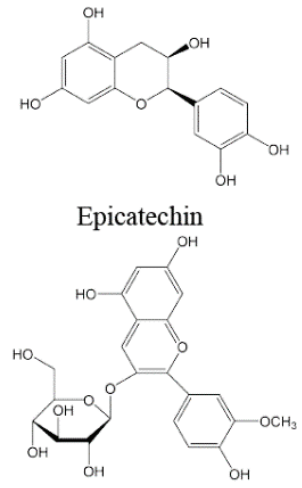

Peonidin 3-glucoside

Fig. 1. Chemical structures of the phenolic compounds frequently found in wine. 
signaling, all of which eventually lead to the death of cancer cells (24). Grape seed extract or red wine polyphenolic compounds can inhibit certain cancer cells by regulating the immune and metabolic systems, such as targeting the enzymes involved in arachidonic acid metabolism in colorectal cancer (25). Several factors alter cell signaling pathways; however, the phenolic compounds in wine, such as flavonoids, can reverse and restore normalcy (18). Currently, more novel mechanisms are needed to prevent and treat cancers. The anticancer effects exhibited by the phenolic components of wine appear complicated as many different pathways are involved and many unidentified mechanisms have yet to be studied.

In this review, we present recent findings pertaining to the anticancer properties of the phenolic compounds of wine. We also summarize protective effects and mechanisms of main bioactive phenolic compounds in wine with a focus on flavonoids and resveratrol.

\section{Wine consumption and health: controversy remains} A 12-year follow-up study showed that low to moderate alcohol consumption, namely 10-14 drinks peer week, was correlated with better total and individual cognitive functions, including word recall, mental status, and vocabulary among 19,887 participants in United States adults (26). Moderate alcohol consumption such as a small glass of wine daily could reduce the risk of ischemic heart disease, diabetes, and ischemic stroke $(27,28)$. In addition, a systematic review and meta-analysis demonstrated that low to moderate alcohol consumption is associated with a reduced risk of 0.75 folds for cardiovascular disease and coronary heart disease mortality, and 0.71 folds for incident coronary heart disease (29). However, another study was conducted to analyze the relationship between lifestyle and genetic risk with the incidence of dementia in a total of 196,383 participants with a mean age of 64.1 years, and the results showed that both an unfavorable lifestyle like moderate alcohol consumption and high genetic risk are strongly associated with higher dementia risk (30). A translational study indicated that chronically alcohol consumption expands mean diffusivity of brain gray matter among humans and rats and is positively associated with a clear decrease in extracellular space tortuosity caused by a microglial reaction (31). However, the relationship between wine consumption and cancer risk still remains elusive. Alcohol consumption is reported to be able to increased risks of cancer, including cancers of the breast, lip, and oral cavity (32). Similarly, a global systematic analysis study regarding the alcohol use and disease burden demonstrated that alcohol consumption is a leading risk factor of cancers (33). On the contrary, some studies suggest that alcohol intake of reasonable quantities, such as low to moderate consumption of wine, may be beneficial for the treatment of several types of cancer $(27,28)$. The anticancer properties of the phenolic compounds in wine are shown in Fig. 2.

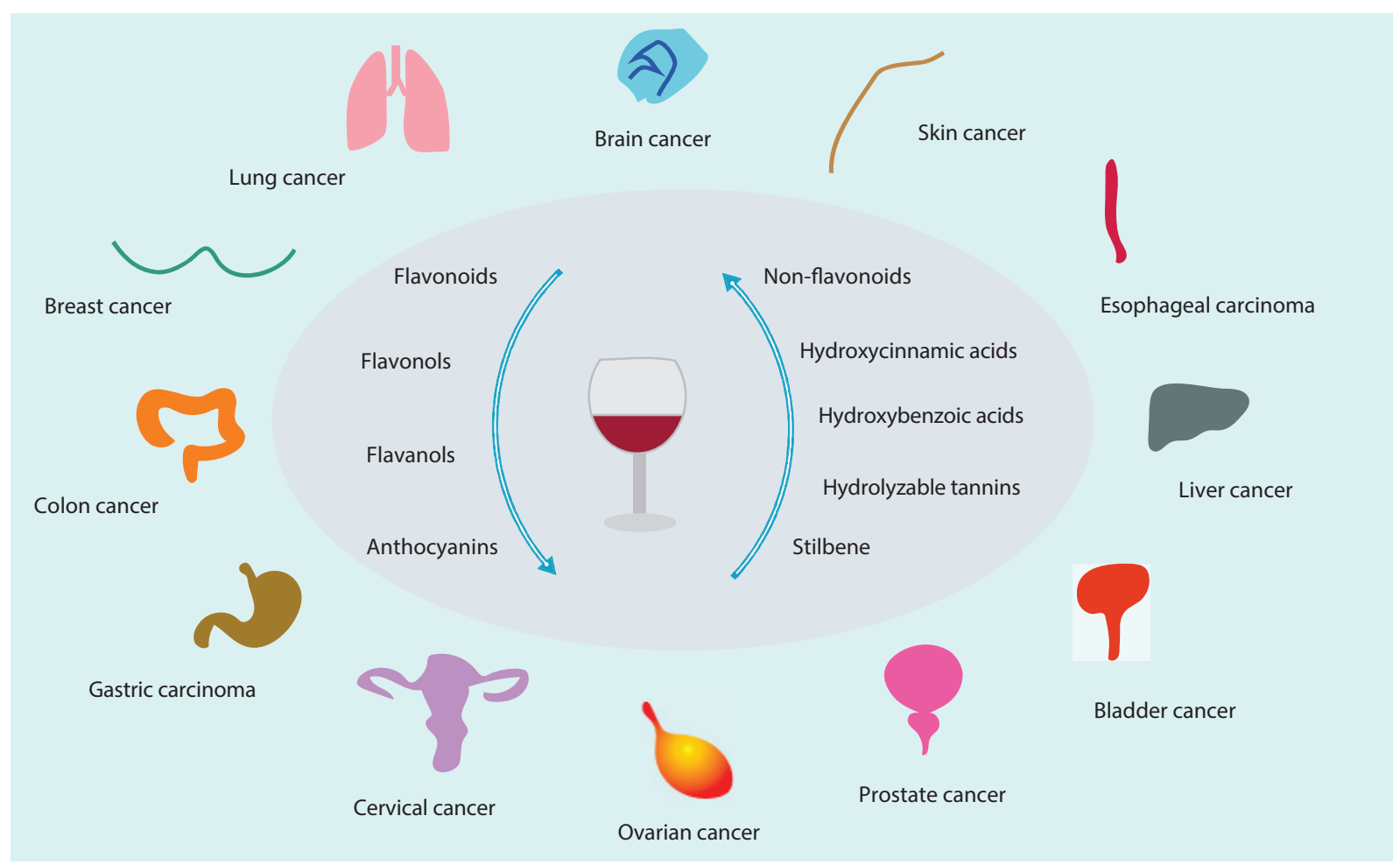

Fig. 2. The major phenolic compounds in wine and the types of cancer that phenolic compounds exert anticancer effects. 
The anticancer effects of flavonoids and their potential mechanisms

Flavonoids are characterized by a $\mathrm{C}_{6}-\mathrm{C}_{3}-\mathrm{C}_{6}$ skeleton, which contains two benzene rings that are connected by a pyran ring in the center. Most phenolic compounds in red wine are flavonoids. The total phenolic content is more than $85 \%$ in red wine but less than $20 \%$ in white wine (34). Flavonols, flavanols, and anthocyanins are the subclasses of flavonoids present in wine. The consumption of flavonoids may reduce the incidence of cancers and improve prognosis. They can inhibit the progression of several types of cancer through inducing programmed cell death, inhibition of cell growth and viability, cell cycle arrest (35, 36 ), and interfering with the metabolic functions associated with the aberrant immune function (37).

\section{Flavonols}

Flavonols are a group of yellow phenolic pigments belonging to the flavonoid family that are found mostly as glycosides, such as glucosides and glucuronides. Flavonols have been shown to inhibit tumorigenesis in in vitro and in vivo models. The most common flavonol in grapes is quercetin, which is present in its skin and stem (38). In the past decades, several anticancer properties of quercetin have been discovered, such as its cell signaling, proapoptotic, antiproliferative, antioxidant, and cell-growth suppression effects. Quercetin exerts its primary antioxidant effect by providing electrons to reduce the levels of ROS, inhibiting tumor cell growth and preventing DNA damage caused by mutations (39). In addition, quercetin exhibits proapoptotic effects in tumor cells through mitochondria-mediated pathways or by increasing cytotoxicity and oxidative stress $(40,41)$. Quercetin also inhibits the proliferation of human hepatoma cell line, HepG2, by altering the expression of the cytochrome $\mathrm{P} 450$ proteins A1 (CYP1A1) gene (42). At low concentrations, quercetin inhibits the proliferation of human breast cancer cells by arresting the cell cycle in G1 phase (43). Additionally, quercetin increases G2/M phase and the levels of p53 and p21 proteins and induces cytotoxicity and apoptosis in lung carcinoma cells (44). Several experimental studies indicate that quercetin may be a promising adjuvant in the chemotherapy of cancers. Quercetin promotes cisplatin-induced apoptosis in oral squamous cell carcinoma by reducing the nuclear factor $\kappa \mathrm{B}(\mathrm{NF}-\kappa \mathrm{B})$ and $\mathrm{x}$-linked inhibitor of apoptosis (xIAP) protein levels and results in the significant inhibition of tumor growth (45). NF- $\kappa \mathrm{B}$ is important for the differentiation of immune cells and is involved in metabolic disorders (46). When combined with metformin, quercetin strongly inhibits the growth, migration, and invasion of prostate cancer cells both in vitro and in vivo through the vascular endothelial growth factor/AKT8 virus oncogene cellular homolog/phosphatidylinositol-3-kinase (VEGF/Akt/PI3K) signaling pathway (47). Furthermore, quercetin can regulate the activity of several tyrosine kinases. In general, the anticancer effects of quercetin are owing to its ability to induce apoptosis, arrest the cell cycle, scavenge free radicals, and regulate proteins such as tyrosine kinases, p53, and heat shock proteins (HSPs) (48). Moreover, it is reported that quercetin modulates immunity to promote the anticancer response by regulating dendritic cells (DCs) activation and decreasing tumor necrosis factor (TNF), interleukin-1 $\beta$ (IL-1 $\beta$ ), IL-6, IL-10, and IL-12p70 secretion (49). Poor water solubility and low bioavailability of quercetin are the limiting factors of its application in a clinical setting for cancer chemoprevention (50). However, quercetin is an indispensable food ingredient, and its bioavailability increases when derived from sources, such as onions or grapes. In the future, nanoparticles or other modes of drug transport will be essential for the effective delivery of quercetin to cancer cells (51).

Besides quercetin, the common flavonols in wine include kaempferol and myricetin. The structures of these compounds are similar. Myricetin, also known as hydroxyquercetin, has an additional - $\mathrm{OH}$ group compared to kaempferol. Epidemiological studies show that kaempferol and myricetin exhibit therapeutic potentials in different types of cancers, including cancers of the bladder, stomach, colon, ovary, pancreas, lungs, breast, and the prostate gland (52-54). They inhibit growth, migration, and invasion of cancer cells and induce apoptosis by activating or inhibiting different signaling pathways and reactivating various key genes involved in tumorigenesis. In breast cancer, kaempferol arrests the cell cycle in the G2/M phase by decreasing the level of cyclin-dependent kinase 1 (CDK1) (55) and inhibiting migration and invasion by blocking the PKC $\delta$ (protein kinase $\mathrm{C}$ )/mitogen-activated protein kinase (MAPK)/activator protein 1 (AP-1) cascade and the expression of MMP-9 (matrix metalloproteinases) (56). Kaempferol induces apoptosis by regulating caspase- 3 expression and the cleavage of poly-ADP-ribose polymerase (PARP), B-cell lymphoma-2 (BCL-2), and Bax (57). Other findings reveal that ROS are the reason for kaempferol in inducing apoptosis (58). Moreover, recent studies demonstrate that kaempferol induces autophagy and cell death by increasing the conversion of light chain 3 (LC3)-I to LC3-II and decreasing the expression of p62 in gastric, hepatic, and lung cancers (59-61). Kaempferol activates the inositol-requiring enzyme 1 (IRE1)1/Jun n-terminal kinase (JNK)/C/EBP homologous protein 10 (CHOP) pathway from the cytosol to the nucleus and promotes autophagic cell death by inhibiting the histone deacetylase (HDAC)/ G9a axis in gastric cancer (62). In hepatic cancer cells, kaempferol induces autophagy through the AMP-activated protein kinase (AMPK)/AKT pathway and decreases the expression of CDK1/cyclin B (61). Myricetin may target a specific molecule or multiple signaling pathways to inhibit 
tumor progression. It is reported that myricetin suppresses breast cancer metastasis by downregulating MMP-2/9 and mRNA ST6GALNAC5 levels in vitro and in vivo (63). Myricetin induces apoptosis in ovarian, skin, and colon cancer cells by upregulating the proapoptosis proteins including Bax, BCL-2, cleaved PARP, and caspase-3 (54). In addition, myricetin was found to downregulate extracellular signal-regulated kinase (ERK)/p90RSK/AP-1, janus-family tyrosine kinase 1 (JAK1)/signal transducer and activator of transcription (STAT), and PI3K/AKT pathways in cancer cells (64). Myricetin demonstrates the immunomodulatory effects by inhibiting $\mathrm{T}$ cell proliferation and reducing the secretion of interferon- $\gamma$ (IFN- $\gamma$ ), IL-2, and IL-17 (65). However, the immunomodulatory effects of cancer immunity by myricetin in vivo are yet to be studied.

\section{Flavanols}

Flavanols, a subclass of flavonoids, are hydroxylated at C3 in the heterocyclic ring. Flavanols are often referred to flavan-3-ols and comprise catechin, epicatechin, epigallocatechin, epicatechin gallate, and proanthocyanidins, which are present in red wine. They react with tannins and lend wines their characteristic flavor (66). Studies suggest that flavanols can reduce the risk of various diseases by maintaining glucose homeostasis, exerting a prebiotic effect on gut microbiota, and enhancing insulin signaling (67). The inhibitory effects of catechin against cancers have been demonstrated in many studies, and prostate cancer is one of the most studied cancer types in anticancer research involving catechin. Catechin has direct as well as indirect effects on cancer cells, and the latter involves affecting the tumor microenvironment (68). The main anticancer inhibitory actions of catechins are by inducing apoptosis in different animal models, reducing the phosphorylation of c-Jun and Erk1/2 levels in lung tumorigenesis models, suppressing phospho-Akt and nuclear $\beta$-catenin levels in colon cancer models, inhibiting the insulin-like growth factor-1 (IGF1)/IGF1 receptor (IGF1R) axis in colon and prostate cancer models, and restraining the VEGF-dependent angiogenesis in lung and prostate cancer models (69-71).

Epicatechin exerts antiproliferative effects in gastric, prostate, ovary, and lung cancers and is able to reduce cisplatin-induced toxicity (72). Epicatechin has been reported to regulate mitochondrial activity by inhibiting phosphorylated Erk2 associated with Ras/MAPK signaling pathway at low concentrations (73). Thus, epicatechin can induce cancer cell death by increasing cell stress and sensitivity. Mitochondrial respiration, ROS production, and Warburg metabolism are the likely mechanisms of action. In addition, epicatechin was found to inhibit the expression of $\mathrm{NF}-\kappa \mathrm{B}, \mathrm{AP}-1$, Akt, and nuclear factor erythroid-2 related factor 2 (Nrf2) pathways, which are important in cell proliferation and survival (74). Mice were treated with either vehicle control group, $1 \mathrm{mg} / \mathrm{kg}$ epicatechin group, or $5 \mathrm{mg} / \mathrm{kg}$ naltrindole (a $\delta$-opioid receptor antagonist) for 10 days, and the results showed that mice of epicatechin-treated group had the highest respiration rates, suggesting that epicatechin has the potential to augment mitochondrial function (75). Epigallocatechin and epicatechin gallate, which have structural similarities with epicatechin, also showed inhibitory effects in oral and prostate cancer through different signaling pathways (76). Epigallocatechin gallate has been reported to inhibit cancer by modulating immune by decreasing Th1 and $\mathrm{CD}^{+} \mathrm{T}$ cells and increasing Tregs (77).

Proanthocyanidins comprise a group of oligomers and polymers of flavanols in grape seeds, which have potent antioxidant and antitumorigenic properties owing to their ability to target multiple oncogenic signaling pathways (78). Epidemiological and clinical studies show an inverse association between proanthocyanidin intake and prostate cancer risk in 43,000 men and in 3,974 incidences of prostate cancers (79). It has been reported that proanthocyanidin administration significantly inhibits cell proliferation and induces apoptosis in oral squamous cell carcinoma, skin cancer, and colon cancer cells by attenuating the PI3K pathway and decreasing phosphorylated Protein Kinase B (PKB) ser(473) levels $(80,81)$. Proanthocyanidins inhibit the growth of prostate cancer cells by reducing the expression of MMP-2 and MMP-9 proteins and regulating androgen receptor-mediated transcription by mediating anti-histone acetyltransferase activity (82). Proanthocyanidins arrest the G0/G1 phase of breast cancer and lung cancer cells by upregulating Cip1/p21 levels and downregulating cyclin levels $(78,83)$. Additionally, proanthocyanidins effectively suppressed the growth of prostate tumors in male transgenic adenocarcinoma of mouse prostate mice (84). However, further studies are required to elucidate the anticancer mechanisms of proanthocyanidins.

\section{Anthocyanins}

Anthocyanins are members of a complex group of natural phenolic glycosides that are responsible for the black and red color of grapes. Anthocyanins found in grapes are limited in number and consist of mixtures of pigment molecules that vary among grape species and varieties. The most common anthocyanins in red wine are cyanidin, delphinidin, peonidin, malvidin, and petunidin (85). Consumption of wine that is rich in anthocyanins has been associated with a reduced risk of cardiovascular disease and cancer. This can be attributed to the regulation of several signaling pathways and crucial cellular processes, including cell cycle, apoptosis, autophagy, and biochemical metabolism, by anthocyanins $(86,87)$. The primary pathways targeted by anthocyanins by which it interferes with the growth of cancer cells include mitogen-activated protein kinase (MAPK), nuclear factor $\kappa \mathrm{B}(\mathrm{NF} \kappa \mathrm{B})$, AMP-activated protein kinase, and $\mathrm{Wnt} / \beta$-catenin (88). It has been 
demonstrated that anthocyanins induce apoptosis of cancer cells by activating caspases and mediating ROS and JNK/p38-MAPK pathway. Moreover, anthocyanins exert metastatic effects through regulating the VEGF signaling pathway and degradation of the extracellular matrix (89). Cyanidin is a common anthocyanidin, which is naturally existed in its glycosylated form as cyanidin-3-glucoside $(\mathrm{C} 3 \mathrm{G}) . \mathrm{C} 3 \mathrm{G}$ is reported to show efficacy in breast cancer, renal cell carcinoma, and colon cancer. $\mathrm{C} 3 \mathrm{G}$ inhibits the migratory and invasion of breast cancer cells by inducing mesenchymal to epithelial transition via increasing epithelial-mesenchymal transition (EMT) and Sirt1 expression (90). This glucoside also inhibits proliferation and tumor growth in breast cancer via caspase-3 cleavage and DNA fragmentation (91). A study shows that $\mathrm{C} 3 \mathrm{G}$ could be potentially used for the prevention or therapy of colon cancer. This study also reveals that $\mathrm{C} 3 \mathrm{G}$ exerts its effect by binding to talin and promoting the interaction of talin with $\beta 1 \mathrm{~A}$-integrin, which negatively correlates to the survival rate of patients with colon cancer (92). At concentrations of 25-100 $\mu \mathrm{M}$, Cyanidin-3-O-glucoside $(\mathrm{C} 3 \mathrm{G})$ inhibits the proliferation of renal cell carcinoma cells and tumorigenesis by arresting the cell cycle, inducing apoptosis and autophagy by regulating the expression of early growth response protein 1 (EGR1), selenoprotein W1 (SEPW1), p62 or sequestosome 1, and autophagy related gene 4 (ATG4) (93). C3G suppresses rheumatoid arthritis by reducing IL- 6 and IFN- $\gamma$, and increasing IL-10 and Tregs (94). However, few studies reported about the immunomodulatory effects of $\mathrm{C} 3 \mathrm{G}$ against cancer progression.

Delphinidin has potent antitumor properties associated with the proliferation, migration, and invasion of cancer cells. At low concentrations, delphinidin suppresses the migratory ability and invasiveness of colorectal cancer cells both in vitro and in vivo by inhibiting the integrin/ FAK axis and upregulating the expression of miR-204-3p (95). Delphinidin prominently inhibits the brain-derived neurotrophic factor (BDNF)-induced increase in cell migration and invasion of SKOV3 ovarian cancer cells by decreasing the expression of MMP-2, MMP-9, and AKT pathways (96) and also inhibits proliferation by participating in the PI3K/AKT and ERK1/2 MAPK signaling cascades (97). In addition, delphinidin induces apoptosis and autophagy by downregulating the expression of caspase-3, caspase-9, and AKT/mammalian target of rapamycin (mTOR) pathway in breast cancer cells (98). Finally, delphinidin has also been shown to induce apoptosis by mediating p53 acetylation and oligomerization in prostate cancer cells (99).

There are a few reports on the anticancer effects of peonidin, malvidin, and petunidin at the molecular level. Peonidin is naturally existed as peonidin 3-glucoside (P3G), its glycosylated form. A study shows that P3G can significantly suppress lung cancer metastasis by attenuating ERK $1 / 2$ and AP-1 and activating the MAPK pathway (100). P3G inhibits the proliferation and tumor growth of lung cancer cells by arresting the G2/M phase via the downregulation of cell cycle-related proteins such as CDK-1, CDK-2, and cyclin B1 (101). Both P3G and C3G showed inhibitory effects on human epidermal growth factor receptor (HER)-positive breast cancer cells in vitro and in vivo. They also promoted the apoptosis of cancer cells and inactivated phospho-HER2 and phospho-AKT (102). Malvidin, at a dose of $200 \mathrm{mg} / \mathrm{mL}$, inhibited the proliferation of several cancer cell lines, including human gastric adenocarcinoma cell line, human colon cancer cell line HCT-116 Michigan cancer foundation - 7 (MCF7) (breast), NCI H460 (lung), and SF-268 (central nervous system) (103). Malvidin-3-galactoside (M3G) inhibited the proliferation, migration, and invasion of HepG2 cells and promoted apoptosis by regulating related proteins, including cleaved caspase-3, MMP-2 and MMP-9, and p-AKT. M3G has also been effective in vivo in inhibiting the growth of liver tumors (104). Petunidin-3-O-glucoside (P3OG) could exhibit a significant antiproliferative effect in glioblastoma multiforme (GBM) by regulating glycolytic metabolism. Moreover, P3OG combined with a PI3K inhibitor could significantly induce GBM cell death by regulating the silent information regulator 3 (SIRT3)/p53 and PI3K/AKT/ERK pathways (105). It is well known that the occurrence of cancer induced by persistent oxidative stress is closely related to the inflammatory status. Phenolic compounds as dietary antioxidants exert a pivotal effect in cancer by preventing oxidative stress through scavenging free radicals (106).

Many studies have identified the molecular targets of these compounds and the effects of these compounds on the prevention and treatment of cancer. However, the understanding of molecular mechanisms in this field is still at an embryonic stage, and more studies are needed to better comprehend the anticancer properties of anthocyanins.

\section{The anticancer effects of non-flavonoids and their potential mechanisms}

Diverse non-flavonoids, which have a simpler structure compared to that of flavonoids, have been identified in wine. Derivatives of hydroxycinnamic and hydroxybenzoic acids are the main non-flavonoids present in wine that has not been aged in oak barrels. They are usually present in the vacuoles of grape cells and can be easily extracted when crushed. These compounds play an important role in the oxidation and subsequent browning of grape juice. Hydrolyzable tannins, such as ellagitannin and gallotannin, are present during the aging of wine in oak barrels. Stilbene in wine is produced in grape skin and leaves in response to the infections on grapevines caused by Botrytis cinerea and other fungi $(2,107)$. 


\section{Hydroxycinnamic acids and hydroxybenzoic acid}

The most common hydroxycinnamic and hydroxybenzoic acids in wine are caffeic, ferulic, chlorogenic, gallic, vanillic, and coumalic acids. Numerous studies have demonstrated the antitumor efficacy of phenolic acids in breast, ovarian, lung, and oral cancers, and in melanomas. Both caffeic and ferulic acid inhibit the proliferation of melanoma cells by downregulating the CK2-induced phosphorylation of tyrosinase, which is important in melanin biosynthesis (108). Caffeic acid prevents the progression of breast cancer cells and promotes cell death by arresting the cell cycle and reducing cyclin D1, IGFIR, and p-AKT levels (109). Moreover, caffeic acid is capable of disrupting energy homeostasis and regulating oxidative metabolism and glycolysis in cervical tumor cells by activating the AMPK signaling pathway and suppressing the expression of hypoxia inducible factor-1 $\alpha$ (HIF-1 $\alpha)$, glucose transporter type 1 (GLUT1), hexokinase 2 (HK2), protein kinase $\mathrm{M}$ (PKM), and lactate dehydrogenase (LDH) (110). Ferulic acid is a potential candidate for the treatment of several diseases, such as Alzheimer's disease, cardiovascular diseases, diabetes mellitus, and cancers of the colon and breast. Ferulic acid suppresses the metastasis of breast cancer cells by mediating epithelial to mesenchymal transition (111). It also suppresses cell proliferation and induces apoptosis in osteosarcoma cells by suppressing the PI3K/AKT pathway and downregulating the cell cycle-related proteins, CDK2 and BCL-2 (112). Moreover, it inhibits the proliferation of human cervical carcinoma cells by inducing cell cycle and autophagy. The cell cycle-related proteins, such as cyclin D1, and the autophagy-related proteins, including LC3II and autophagy associated genes (ATG) families, are reported to be regulated by ferulic acid (113). In an in vivo study, ferulic acid was administered to male F344 rats with azoxymethane (AOM)-induced colon carcinogenesis, which resulted in the inhibition of tumor growth (114).

Besides caffeic and ferulic acids, several other phenolic acids in wine show potential anticancer effects and the mechanism of anticancer including the induction of cell cycle arrest, inhibition of cell proliferation, reduction of ROS production, induction of apoptosis and autophagy, and the reduction of migration and invasion. The primary mechanisms of chlorogenic acid against cancer include inhibiting the AMPK, hypoxia inducible factor (HIF), VEGF, PI3K, and MAPK/ ERK pathways (115). For instance, chlorogenic acid motivates apoptosis in human renal cell carcinoma by activating the caspase protein and inhibiting the PI3K/ AKT/mTOR pathway (116). Gallic acid inhibits cancer cell growth by mediating the modulation of genes that encode for cell cycle proteins, metastasis, angiogenesis, and apoptosis. The main mechanism of gallic acid against cancer is by activating the $\mathrm{NF}-\kappa \mathrm{B}$ and $\mathrm{AKT}$ pathways and attenuating the activity of cyclooxygenase, ribonucleotide reductase, and glutathione (117). Gallic acid inhibited the migration and invasion of human nasopharyngeal carcinoma cells by decreasing the expression of MMP-1, AP-1, and E26-AMV virus oncogene cellular homolog (ETS-1) (118). In addition, vanillic acid significantly arrested the G1 phase and inhibited the proliferation of human colon cancer in vitro and in vivo by suppressing the HIF-1 $\alpha$ expression and inhibiting the $\mathrm{mTOR} / \mathrm{p} 70 \mathrm{~S} 6 \mathrm{~K} / \mathrm{eIF} 4 \mathrm{E}$ binding protein 1 (4E-BP1) and Raf/MEK (Mitogen-activated protein kinase)/ERK pathways (119). Coumaric acid showed its inhibitory effect in the lung (A549), colon (Caco-2), breast (MCF7), hepatic (HepG2), and neuroblastoma (N2a) cancer cell lines. Coumaric acid exerts its anticancer effect as an antioxidant, by depletion of ROS, which has a distinct impact on cellular functions (120).

\section{Hydrolyzable tannins}

Hydrolyzable tannins in wine are only present in wine fermented in oak barrels and not in grapes. They hydrolyze into their respective acid and alcohol components during the aging of wine, which is of great importance for flavor development. Ellagitannins (ET) and gallotannins (GT) are the most common hydrolyzable tannins in wine, which can be hydrolyzed into ellagic and gallic acids, respectively. Many studies show that ET, GT, and their derivatives, such as ellagic and gallic acids, have chemopreventive and chemotherapeutic activities in prostate, colon, breast, oral, esophageal, gastric, liver, cervical, lung, and skin cancers (121-124). ET inhibited the proinflammatory pathways by suppressing the $\mathrm{NF}-\kappa \mathrm{B}$. The anti-inflammatory activity could enhance the antioxidant capacity of ET by reducing the levels of free radicals (125). The antiproliferative activity of ET is owing to other mechanisms, which involve its participation in cell cycle arrest, apoptosis, mitochondrial pathways, migration and invasion, metastasis, and angiogenesis. For instance, ET inhibited the proliferation of colon cancer cells and promoted the apoptosis of colon cancer cells by anti-inflammatory effect through activating the AKT pathway and suppressing the $\mathrm{NF}-\kappa \mathrm{B}$ pathway (126). Another study reports that ET and its derivatives inhibit the proliferation of HT-29 cells by arresting $\mathrm{G} 0 / \mathrm{G} 1$ and $\mathrm{G} 2 / \mathrm{M}$ phases and regulating the cell cycle-related proteins (127).

Similar to ellagitannins, gallotannins exert anticancer effects by virtue of multiple mechanisms, including the suppression of proliferation and colony formation, arresting cell cycle, inducing apoptosis and autophagy, increasing p21 level and SA- $\beta$-Gal activity, and regulating the AIRT1/AMPK pathway (128). However, the health benefits of gallotannins have rarely been discussed because they are not absorbable after consumption (129). 
Table 2. Effects of the main phenolic compounds of wine in different cancer types

\begin{tabular}{|c|c|c|c|}
\hline $\begin{array}{l}\text { Phenolic } \\
\text { compounds }\end{array}$ & Cancer type & Biological effects & Reference \\
\hline \multirow[t]{6}{*}{ Quercetin } & $\begin{array}{l}\text { Esophageal squamous } \\
\text { carcinoma cells }\end{array}$ & $\begin{array}{l}\text { Proapoptotic effects through mitochondria-mediated pathways or by increasing } \\
\text { cytotoxicity and oxidative stress }\end{array}$ & $(40)$ \\
\hline & Hepatocarcinoma cells & $\begin{array}{l}\text { Proapoptotic effects by increasing the cytotoxicity and oxidative stress, and inhib- } \\
\text { its cell proliferation by altering the CYPIAI level }\end{array}$ & $(41,42)$ \\
\hline & Breast cancer cells & Inhibits proliferation by arresting the cell cycle in GI phase & $(43)$ \\
\hline & Lung carcinoma cells & Proapoptotic effects by increasing G2/M phase, $\mathrm{p} 53$ and $\mathrm{p} 2 \mathrm{I}$ levels, and induces cytotoxicity & (44) \\
\hline & Oral squamous cell carcinoma & Proapoptotic effects by reducing the NF- $\mathrm{KB}$ and $\mathrm{xIAP}$ levels & $(45)$ \\
\hline & Prostate cancer & Inhibits the growth, migration, and invasion through the VEGF/Akt/PI3K pathway & (47) \\
\hline \multirow[t]{2}{*}{ Kaempferol } & Breast cancer cells & $\begin{array}{l}\text { Arrests the cell cycle, inhibits migration and invasion through the PKC } \delta / M A P K / \\
\text { AP-I pathway and the MMP- } 9 \text { level, and induces apoptosis by regulating the cleav- } \\
\text { age of PARP, BCL-2, and Bax }\end{array}$ & $(55-57)$ \\
\hline & Gastric, hepatic, and lung cancers & Induces autophagy by increasing the conversion of LC3-I to LC3-II & $(59-61)$ \\
\hline \multirow[t]{2}{*}{ Myricetin } & Breast cancer & $\begin{array}{l}\text { Suppresses cancer metastasis by downregulating MMP- } 2 / 9 \text { and mRNA ST6GAL- } \\
\text { NAC5 levels }\end{array}$ & (63) \\
\hline & $\begin{array}{l}\text { Ovarian, skin, and colon } \\
\text { cancer cells }\end{array}$ & Induces apoptosis by upregulating the Bax, BCL-2, cleaved PARP, and caspase-3 levels & (54) \\
\hline \multirow[t]{3}{*}{ Catechin } & Lung cancer & Induces apoptosis by reducing the levels of $\mathrm{c}$-Jun and Erkl/2 & (69) \\
\hline & Colon cancer & Induces apoptosis by suppressing phospho-Akt and nuclear $\beta$-catenin levels & (70) \\
\hline & Prostate cancer & Inhibits the IGF/IGFIR axis and restrains the VEGF-dependent angiogenesis & (7I) \\
\hline Epicatechin & Hepatocarcinoma cells & Inhibits proliferation by regulating the NF-KB,AP-I,Akt, and Nrf2 pathways & (74) \\
\hline \multirow[t]{3}{*}{ Proanthocyanidins } & $\begin{array}{l}\text { Oral squamous cell carcinoma, } \\
\text { skin cancer, and colon cancer cells }\end{array}$ & $\begin{array}{l}\text { Inhibits proliferation and induces apoptosis by regulating the PI3K pathway and } \\
\text { decreasing PKB ser (473) phosphorylation levels }\end{array}$ & $(80,8 \mathrm{I})$ \\
\hline & Prostate cancer cells & Reduces the MMP-2 and MMP-9 levels & (82) \\
\hline & $\begin{array}{l}\text { Breast cancer and lung } \\
\text { cancer cells }\end{array}$ & Arrests the G0/G I phase by increasing Cipl/p2I levels and decreasing cyclin levels & $(78,83)$ \\
\hline \multirow[t]{2}{*}{$\begin{array}{l}\text { Cyanidin-3-glu- } \\
\text { coside }\end{array}$} & Breast cancer cells & $\begin{array}{l}\text { Inhibits migration and invasion by increasing the EMT and Sirt I expression, and } \\
\text { inhibits proliferation via caspase- } 3 \text { cleavage and DNA fragmentation }\end{array}$ & $(90,91)$ \\
\hline & Renal cell carcinoma cells & Inhibits proliferation by regulating the EGRI, SEPWI, p62, and ATG4 levels & $(93)$ \\
\hline \multirow[t]{4}{*}{ Delphinidin } & Colorectal cancer & Inhibits the integrin/FAk axis and upregulates the expression of miR-204-3p & $(95)$ \\
\hline & Ovarian cancer cells & $\begin{array}{l}\text { Decreases the expression of MMP-2, MMP-9, AKT pathways, PI3K/AKT, and } \\
\text { ERKI/2 MAPK pathways }\end{array}$ & $(96,97)$ \\
\hline & Breast cancer cells & Induces apoptosis and autophagy & (98) \\
\hline & Prostate cancer cells & Mediates p53 acetylation and oligomerization & (99) \\
\hline $\begin{array}{l}\text { Peonidin } \\
\text { 3-glucoside }\end{array}$ & Lung cancer & $\begin{array}{l}\text { Regulates ERK I/2 and AP-I levels, the MAPK pathway, and cell cycle-related } \\
\text { proteins }\end{array}$ & $(99,101)$ \\
\hline $\begin{array}{l}\text { Malvidin } \\
\text { 3-galactoside }\end{array}$ & Hepatocellular carcinoma & Regulates the cleaved caspase-3, MMP-2 and MMP-9, and p-AKT levels & $(104)$ \\
\hline $\begin{array}{l}\text { Petuni- } \\
\text { din-3-O-glucoside }\end{array}$ & Glioblastoma multiforme & Inhibits proliferation by regulating glycolytic metabolism & $(105)$ \\
\hline \multirow[t]{2}{*}{ Caffeic acid } & Breast cancer cells & Reduces cyclin DI, IGFIR, and p-AKT levels & $(109)$ \\
\hline & Cervical tumor cells & $\begin{array}{l}\text { Activates the AMPK pathway and the expression of HIF-I } \alpha \text {, GLUTI, HK2, PKM, } \\
\text { and LDH }\end{array}$ & $(110)$ \\
\hline \multirow[t]{2}{*}{ Ferulic acid } & Osteosarcoma cells & Suppresses the PI3K/AKT pathway and downregulates the CDK2 and BCL-2 levels & $(112)$ \\
\hline & Cervical carcinoma cells & Induces cell cycle and autophagy & $(113)$ \\
\hline Ellagitannins & Colon cancer cells & $\begin{array}{l}\text { Inhibits the proinflammatory pathways, activates the AKT pathway, and suppresses } \\
\text { the NF-KB pathway }\end{array}$ & $(125,126)$ \\
\hline Gallotannins & Hepatocellular carcinoma cells & Increases $\mathrm{p} 2 \mathrm{I}$ level and SA- $\beta-$ Gal activity and regulates the AIRTI/AMPK pathway & (128) \\
\hline \multirow[t]{4}{*}{ Resveratrol } & Lung cancer cells & Decreases the NADPH activity and actuates the Nrf2 pathway & $(134)$ \\
\hline & Breast cancer cells & $\begin{array}{l}\text { Modulates the activity of FOXO3a and inhibits the expression of VEGF, EGFR, } \\
\text { and FGF-2 }\end{array}$ & $(140,146)$ \\
\hline & Epidermoid carcinoma & Increases the caspase- 3 level and the $\mathrm{p} 2 \mathrm{I} / \mathrm{WAFI} / \mathrm{CIP}$ pathway & $(143)$ \\
\hline & Colorectal cancer & Increases the levels of IL-6, IL-8, and Th I 7 & (147) \\
\hline
\end{tabular}




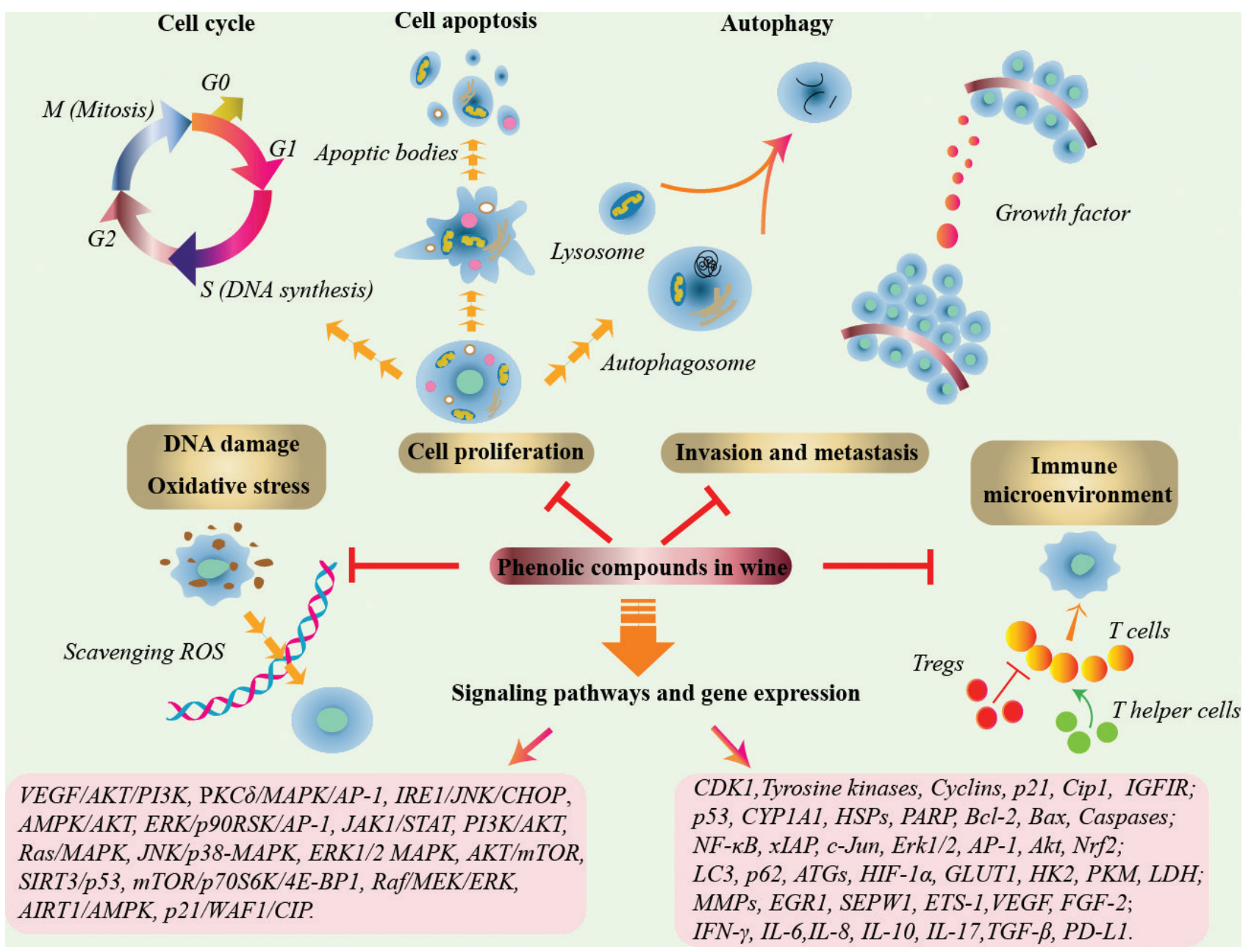

Fig. 3. The summary of major mechanisms by phenolic compounds in wine against cancer action.

\section{Stilbenes (Resveratrol)}

Resveratrol is the most biologically active stilbene monomer in wine, which is generated when grapevines are infected by Botrytis spp. and other fungi (2). All cis and trans isomers of resveratrol have been reported to be found in wine. The average concentration of total resveratrol is 7 $\mathrm{mg} / \mathrm{L}$ in red wine, $2 \mathrm{mg} / \mathrm{L}$ in rose wine, and $0.5 \mathrm{mg} / \mathrm{L}$ in white wine (130, 131). The first study in 1997 demonstrated the anticancer activity of resveratrol (11). Since then, for decades, numerous studies have reported the potent and protective effects of resveratrol against various types of cancers. Resveratrol has been shown to be effective in lung, breast, skin, gastric, colon, cervical, uterine, liver, eye, blood, kidney, prostate, brain, bladder, thyroid, head, esophageal, ovarian, and bone cancers (132). Resveratrol exhibits anticancer effects by modulating multiple cell signaling molecules, proteins involved in cell survival and cell proliferation, and various cell signaling pathways. Resveratrol inhibits cancer in the initiation stage by suppressing the oxidative stress by increasing the activity of the antioxidant enzymes and preventing DNA damage by scavenging ROS
(133). Resveratrol also decreases the nicotinamide adenine dinucleotide phosphate (NADPH) activity and actuates the Nrf2 signaling pathway (134). Studies show that resveratrol exerts antiproliferative effects at the tumor-promotion stage by arresting the cell cycle via regulating the cell cycle-related proteins and p53-dependent pathway. It also induces apoptosis by activating the mitochondrial apoptosome and the death receptor pathways $(135,136)$. Resveratrol triggers apoptosis by inhibiting the PI3K/AKT/mTOR

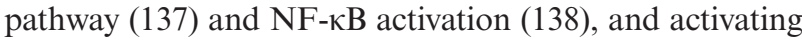
the MAPK pathway (139). Resveratrol has also been found to modulate the activity of FOXO3a in human breast cancer cells (140). It shows an antiproliferative effect in lung cancer by suppressing the expression of phosphorylation of $\mathrm{Rb}$ protein and transcription factors, including AP-1 and $N F-\kappa B$ (141), arresting the G1 phase of the cell cycle through mediating the transforming growth factor- $\beta$ pathway (142), and inducing the apoptosis by increasing the activities of caspase-3 and the p21/WAF1/CDK-interacting protein (CIP) pathway (143). Resveratrol inhibits cell migration and invasion at the tumor-progression stage by 
suppressing the extracellular matrix and basement membrane by regulating matrix metalloproteinases (144).

In addition, resveratrol has been reported to induce immune response in tumor cells by reducing the Th17 production and IL-17 secretion, which play a crucial role in immunologic processes (145). It is known that IL-17 can promote tumor angiogenesis by increasing VEGF levels in tumor cells. Studies also show that resveratrol inhibits angiogenesis-related proteins such as VEGF, epidermal growth factor receptor and fibroblast growth factor 2 (FGF-2) (146). IL-17 can enhance the levels of IL-6 and IL-8, while Th17 has been demonstrated to inhibit the antitumor effect by decreasing T-CD $8^{+}$cells. Th17 also influences the expression of transforming growth factor $\beta$ (TGF- $\beta$ ), CD39, and CD73 ectonucleotides $(147,148)$. In tumors, resveratrol has been shown to reduce the TGF- $\beta$ level in vivo and increase the IFN- $\gamma$ production in T-CD $8^{+}$cells $(149,150)$. Resveratrol enhances the function of T-cell by directly targeting programmed cell death 1 ligand 1 (PD-L1) as an immunomodulating mechanism in cancer cells (151).

However, clinical studies on the tumor-inhibition effect of resveratrol in cancer patients are limited. Some studies suggest that patients with colon and prostate cancers treated with resveratrol prior to surgery are benefitted more than those not receiving resveratrol (152). The sample sizes in these clinical trials are not large or representative, therefore, additional studies are warranted.

\section{Conclusion}

Wine is the alcoholic drink rich in phenolic compounds. Several studies have suggested that the moderate consumption of wine may have health benefits owing to its phenolic compounds. These phytochemicals showed significant chemoprotective and chemotherapeutic effects in almost all types of human cancers. The major functions of wine phenolic compounds on different cancer types are summarized in Table 2. The mechanisms of action of these phenolic compounds against cancer in vitro and in vivo, including DNA damage and scavenging ROS, induction of cell proliferation, arresting cell cycle, programmed cell death, invasion and metastasis, immunity and metabolism, regulation of multiple signaling molecules, and gene expression have been discussed (Fig. 3). However, most of these mechanisms are complex, and the effects and underlying molecular mechanisms of some of the phenolic compounds in wine, such as phenolic acids, still remain to be investigated. In the future, the effects of wine on human health, including its anticancer effects, need to be further explored.

Despite the beneficial anticancer effects of phenolic compounds in wine, many challenges have yet to be overcome. The first challenge is bioavailability, and there are still limited studies on their pharmacokinetics in humans. The absorption and bioavailability of wine-derived phenolic compounds are not well but better with daily diet.
Nanoparticles have been extensively studied to deliver anticancer drugs because of their enhanced anticancer potential and promising clinical application. The other challenge is the use of phenolic compounds as an adjuvant in radiotherapy or chemotherapy with established anticancer drugs such as cisplatin and gefitinib. The combined therapies have great prospects and potential because the use of phenolic compounds can reduce the dose of anticancer drugs and, therefore, reduce side effects. In addition, experimental and clinical studies to further study the anticancer potential of wine-derived phenolic compounds and elucidate their mechanisms of action are required.

\section{Acknowledgments}

This research was funded by the Natural Science Basic Research Program of Shaanxi (2021JQ-161), the National Natural Science Funds for Distinguished Young Scholar (81425025), the Key Project of the National Natural Science Foundation of China (81830093), the CAMS Innovation Fund for Medical Sciences (CIFMS; 2019I2M-1-003), and the National Natural Science Foundation of China (81672765 and 81802796).

\section{Conflict of interest and funding}

The authors have not received any funding or benefits from industry or elsewhere to conduct this study.

\section{References}

1. Arranz S, Chiva-Blanch G, Valderas-Martinez P, MedinaRemon A, Lamuela-Raventos RM, Estruch R. Wine, beer, alcohol and polyphenols on cardiovascular disease and cancer. Nutrients 2012; 4: 759-81. doi: 10.3390/nu4070759

2. Stockley C, Teissedre PL, Boban M, Di Lorenzo C, Restani P. Bioavailability of wine-derived phenolic compounds in humans: a review. Food Funct 2012; 3: 995-1007. doi: 10.1039/ c2fo10208k

3. Waterhouse AL. Wine phenolics. Annals of the New York Academy of Sciences 2002; 957: 21-36. doi: 10.1111/j.17496632.2002.tb02903.x

4. Vuorinen H, Maatta K, Torronen R. Content of the flavonols myricetin, quercetin, and kaempferol in Finnish berry wines. J Agric Food Chem 2000; 48: 2675-80. doi: 10.1021/Jf991388o

5. Ritchey JG, Waterhouse AL. A standard red wine: monomeric phenolic analysis of commercial cabernet sauvignon wines. Am J Enol Viticultre 1999; 50: 91-100. doi: 10.1007/ s001220051078

6. Kovac V, Alonso E, Bourzeix M, Revilla E. Effect of several enological practices on the content of catechins and proanthocyanidins of red wines. J Agric Food Chem 1992; 40: 1953-7. doi: 10.1021/Jf00022a045

7. Mazza G, Fukumoto L, Delaquis P, Girard B, Ewert B. Anthocyanins, phenolics, and color of Cabernet Franc, Merlot, and Pinot Noir wines from British Columbia. J Agric Food Chem 1999; 47: 4009-17. doi: 10.1021/Jf990449f

8. Nixdorf SL, Hermosin-Gutierrez I. Brazilian red wines made from the hybrid grape cultivar Isabel: phenolic composition and antioxidant capacity. Anal Chim Acta 2010; 659: 208-15. doi: 10.1016/j.aca.2009.11.058 
9. Pocock KF, Sefton MA, Williams PJ. Taste thresholds of phenolic extracts of French and American Oakwood - the influence of oak phenols on wine flavor. Am J Enol Vitic 1994; 45: 429-34. doi: 10.1016/0924-2244(94)90074-4

10. Trela BC, Waterhouse AL. Resveratrol: isomeric molar absorptivities and stability. J Agric Food Chem 1996; 44: 1253-7. doi: 10.1021/Jf9504576

11. Jang MS, Cai EN, Udeani GO, Slowing KV, Thomas CF, Beecher CWW, et al. Cancer chemopreventive activity of resveratrol, a natural product derived from grapes. Science 1997; 275: 218-20. doi: 10.1126/science.275.5297.218

12. Ruf JC. Overview of epidemiological studies on wine, health and mortality. Drugs Exp Clin Res 2003; 29: 173-9. doi: 10.1358/dot.2003.39.1.740206

13. German JB, Walzem RL. The health benefits of wine. Annu Rev Nutr 2000; 20: 561-93. doi: 10.1146/annurev.nutr.20.1.561

14. Apostolidou C, Adamopoulos K, Lymperaki E, Iliadis S, Papapreponis P, Kourtidou-Papadeli C. Cardiovascular risk and benefits from antioxidant dietary intervention with red wine in asymptomatic hypercholesterolemics. Clin Nutr ESPEN 2015; 10: e224-33. doi: 10.1016/j.clnesp.2015.08.001

15. Robbins KS, Greenspan P, Pegg RB. Effect of pecan phenolics on the release of nitric oxide from murine RAW 264.7 macrophage cells. Food Chem 2016; 212: 681-7. doi: 10.1016/j. foodchem.2016.06.018

16. Fernandes I, Marques F, de Freitas V, Mateus N. Antioxidant and antiproliferative properties of methylated metabolites of anthocyanins. Food Chem 2013; 141: 2923-33. doi: 10.1016/j. foodchem.2013.05.033

17. Koosha S, Alshawsh MA, Yeng LC, Seyedan A, Mohamed Z. An association map on the effect of flavonoids on the signaling pathways in colorectal cancer. Int J Med Sci 2016; 13: 374-85. doi: 10.7150/ijms. 14485

18. Fernandes I, Perez-Gregorio R, Soares S, Mateus N, de Freitas $\mathrm{V}$. Wine flavonoids in health and disease prevention. Molecules 2017; 22: 292. doi: 10.3390/Molecules22020292

19. Mattioli AV, Farinetti A, Gelmini R. Polyphenols, mediterranean diet, and colon cancer. Support Care Cancer 2019; 27: 4035-6. doi: 10.1007/s00520-019-04835-9

20. Kwon Y. Food-derived polyphenols inhibit the growth of ovarian cancer cells irrespective of their ability to induce antioxidant responses. Heliyon 2018; 4: e00753. doi: 10.1016/j. heliyon.2018.e00753

21. Braakhuis AJ, Campion P, Bishop KS. Reducing breast cancer recurrence: the role of dietary polyphenolics. Nutrients 2016; 8: 547. doi: 10.3390/nu8090547

22. Zhou QY, Pan H, Li J. Molecular insights into potential contributions of natural polyphenols to lung cancer treatment. Cancers 2019; 11: 1565. doi: 10.3390/Cancers 11101565

23. Lall RK, Syed DN, Adhami VM, Khan MI, Mukhtar H. Dietary polyphenols in prevention and treatment of prostate cancer. Int J Mol Sci 2015; 16: 3350-76. doi: 10.3390/ijms16023350

24. Brown L, Kroon PA, Das DK, Das S, Tosaki A, Chan V, et al. The biological responses to resveratrol and other polyphenols from alcoholic beverages. Alcohol Clin Exp Res 2009; 33: 1513-23. doi: 10.1111/j.1530-0277.2009.00989.x

25. Leifert WR, Abeywardena MY. Grape seed and red wine polyphenol extracts inhibit cellular cholesterol uptake, cell proliferation, and 5-lipoxygenase activity. Nutr Res 2008; 28: 842-50. doi: 10.1016/j.nutres.2008.09.001

26. Zhang R, Shen L, Miles T, Shen Y, Cordero J, Qi Y, et al. Association of low to moderate alcohol drinking with cognitive functions from middle to older age among US adults. JAMA Netw Open 2020; 3: e207922. doi: 10.1001/ jamanetworkopen.2020.7922

27. Di Castelnuovo A, Costanzo S, Bagnardi V, Donati MB, Iacoviello L, de Gaetano G. Alcohol dosing and total mortality in men and women: an updated meta-analysis of 34 prospective studies. Archiv Intern Med 2006; 166: 2437-45. doi: 10.1001/ archinte.166.22.2437

28. Howard AA, Arnsten JH, Gourevitch MN. Effect of alcohol consumption on diabetes mellitus: a systematic review. Ann Intern Med 2004; 140: 211-9. doi: 10.7326/0003-4819140-6-200403160-00011

29. Ronksley PE, Brien SE, Turner BJ, Mukamal KJ, Ghali WA. Association of alcohol consumption with selected cardiovascular disease outcomes: a systematic review and meta-analysis. BMJ 2011; 342: d671. doi: 10.1136/bmj.d671

30. Lourida I, Hannon E, Littlejohns TJ, Langa KM, Hypponen E, Kuzma E, et al. Association of lifestyle and genetic risk with incidence of dementia. JAMA 2019; 322: 430-7. doi: 10.1001/ jama.2019.9879

31. De Santis S, Cosa-Linan A, Garcia-Hernandez R, Dmytrenko L, Vargova L, Vorisek I, et al. Chronic alcohol consumption alters extracellular space geometry and transmitter diffusion in the brain. Sci Adv 2020; 6: eaba0154. doi: 10.1126/sciadv. aba0154

32. Collaborators GBDRF, Forouzanfar MH, Alexander L, Anderson HR, Bachman VF, Biryukov S, et al. Global, regional, and national comparative risk assessment of 79 behavioural, environmental and occupational, and metabolic risks or clusters of risks in 188 countries, 1990-2013: a systematic analysis for the Global Burden of Disease Study 2013. Lancet 2015; 386: 2287-323. doi: 10.1016/S0140-6736(15)00128-2

33. Collaborators GBDA. Alcohol use and burden for 195 countries and territories, 1990-2016: a systematic analysis for the Global Burden of Disease Study 2016. Lancet 2018; 392: 1015-35. doi: 10.1016/S0140-6736(18)31310-2

34. Soleas GJ, Diamandis EP, Goldberg DM. Wine as a biological fluid: history, production, and role in disease prevention. J Clin Lab Anal 1997; 11: 287-313. doi: 10.1002/ (Sici)1098-2825(1997)11:5<287::Aid-Jcla6>3.0.Co;2-4

35. Chang H, Lei L, Zhou Y, Ye F, Zhao G. Dietary flavonoids and the risk of colorectal cancer: an updated meta-analysis of epidemiological studies. Nutrients 2018; 10: 950. doi: 10.3390/nu10070950

36. George VC, Dellaire G, Rupasinghe HPV. Plant flavonoids in cancer chemoprevention: role in genome stability. J Nutr Biochem 2017; 45: 1-14. doi: 10.1016/j.jnutbio.2016.11.007

37. Farzaei MH, Singh AK, Kumar R, Croley CR, Pandey AK, Coy-Barrera E, et al. Targeting inflammation by flavonoids: novel therapeutic strategy for metabolic disorders. Int J Mol Sci 2019; 20: 4957. doi: 10.3390/ijms20194957

38. Price SF, Breen PJ, Valladao M, Watson BT. Cluster sun exposure and quercetin in pinot-noir grapes and wine. Am J Enol Vitic 1995; 46: 187-94.

39. Awad HM, Boersma MG, Vervoort J, Rietjens IMCM. Peroxidase-catalyzed formation of quercetin quinone methide-glutathione adducts. Archiv Biochem Biophys 2000; 378: 224-33. doi: 10.1006/abbi.2000.1832

40. Zhang Q, Zhao XH, Wang ZJ. Cytotoxicity of flavones and flavonols to a human esophageal squamous cell carcinoma cell line (KYSE-510) by induction of G2/M arrest and apoptosis. Toxicol In Vitro 2009; 23: 797-807. doi: 10.1016/j.tiv.2009.04.007

41. Tan J, Wang B, Zhu L. Regulation of survivin and Bcl-2 in HepG2 cell apoptosis induced by quercetin. Chem Biodivers 2009; 6: 1101-10. doi: 10.1002/cbdv.200800141 
42. Kang ZC, Tsai SJ, Lee H. Quercetin inhibits benzo[a]pyrene-induced DNA adducts in human Hep G2 cells by altering cytochrome P-450 1A1 gene expression. Nutr Cancer 1999; 35: 175-9. doi: 10.1207/S15327914NC352_12

43. Jeong JH, An JY, Kwon YT, Rhee JG, Lee YJ. Effects of low dose quercetin: cancer cell-specific inhibition of cell cycle progression. J Cell Biochem 2009; 106: 73-82. doi: 10.1002/ jcb. 21977

44. Kuo PC, Liu HF, Chao JI. Survivin and p53 modulate quercetin-induced cell growth inhibition and apoptosis in human lung carcinoma cells. J Biol Chem 2004; 279: 55875-85. doi: 10.1074/ jbc.M407985200

45. Li X, Guo S, Xiong XK, Peng BY, Huang JM, Chen MF, et al. Combination of quercetin and cisplatin enhances apoptosis in OSCC cells by downregulating XIAP through the NF-kappaB pathway. J Cancer 2019; 10: 4509-21. doi: 10.7150/jca.31045

46. Baker RG, Hayden MS, Ghosh S. NF-kappaB, inflammation, and metabolic disease. Cell Metab 2011; 13: 11-22. doi: 10.1016/j.cmet.2010.12.008

47. Sun S, Gong F, Liu P, Miao Q. Metformin combined with quercetin synergistically repressed prostate cancer cells via inhibition of VEGF/PI3K/Akt signaling pathway. Gene 2018; 664: 50-7. doi: 10.1016/j.gene.2018.04.045

48. Shafabakhsh R, Asemi Z. Quercetin: a natural compound for ovarian cancer treatment. J Ovarian Res 2019; 12: 55. doi: 10.1186/s13048-019-0530-4

49. Huang RY, Yu YL, Cheng WC, OuYang CN, Fu E, Chu CL. Immunosuppressive effect of quercetin on dendritic cell activation and function. J Immunol 2010; 184: 6815-21. doi: 10.4049/ jimmunol.0903991

50. Nam JS, Sharma AR, Nguyen LT, Chakraborty C, Sharma G, Lee SS. Application of bioactive quercetin in oncotherapy: from nutrition to nanomedicine. Molecules 2016; 21: E108. doi: 10.3390/molecules21010108

51. Vinayak M, Maurya AK. Quercetin loaded nanoparticles in targeting cancer: recent development. Anticancer Agents Med Chem 2019; 19: 1560-76. doi: 10.2174/18715206196661907051 50214

52. Imran M, Salehi B, Sharifi-Rad J, Aslam Gondal T, Saeed F, Imran A, et al. Kaempferol: a key emphasis to its anticancer potential. Molecules 2019;24:2277. doi: 10.3390/molecules 24122277

53. Neuhouser ML. Dietary flavonoids and cancer risk: evidence from human population studies. Nutr Cancer 2004; 50: 1-7. doi: 10.1207/s15327914nc5001_1

54. Afroze N, Pramodh S, Hussain A, Waleed M, Vakharia K. A review on myricetin as a potential therapeutic candidate for cancer prevention. 3 Biotech 2020; 10: 211. doi: 10.1007/ s13205-020-02207-3

55. Akram M, Iqbal M, Daniyal M, Khan AU. Awareness and current knowledge of breast cancer. Biol Res 2017; 50: 33. doi: 10.1186/s40659-017-0140-9

56. Li C, Zhao Y, Yang D, Yu Y, Guo H, Zhao Z, et al. Inhibitory effects of kaempferol on the invasion of human breast carcinoma cells by downregulating the expression and activity of matrix metalloproteinase-9. Biochem Cell Biol 2015; 93: 16-27. doi: 10.1139/bcb-2014-0067

57. Yi X, Zuo J, Tan C, Xian S, Luo C, Chen S, et al. Kaempferol, a flavonoid compound from gynura medica induced apoptosis and growth inhibition in Mcf-7 breast cancer cell. Afr J Tradit Complement Altern Med 2016; 13: 210-5. doi: 10.21010/ ajtcam.v13i4.27

58. Liao W, Chen L, Ma X, Jiao R, Li X, Wang Y. Protective effects of kaempferol against reactive oxygen species-induced hemolysis and its antiproliferative activity on human cancer cells. Eur J Med Chem 2016; 114: 24-32. doi: 10.1016/j. ejmech.2016.02.045

59. Han X, Liu CF, Gao N, Zhao J, Xu J. Kaempferol suppresses proliferation but increases apoptosis and autophagy by up-regulating microRNA-340 in human lung cancer cells. Biomed Pharmacother 2018; 108: 809-16. doi: 10.1016/j. biopha.2018.09.087

60. Zhang F, Ma C. Kaempferol suppresses human gastric cancer SNU-216 cell proliferation, promotes cell autophagy, but has no influence on cell apoptosis. Braz J Med Biol Res 2019; 52: e7843. doi: 10.1590/1414-431X20187843

61. Huang WW, Tsai SC, Peng SF, Lin MW, Chiang JH, Chiu YJ, et al. Kaempferol induces autophagy through AMPK and AKT signaling molecules and causes G2/M arrest via downregulation of CDK1/cyclin B in SK-HEP-1 human hepatic cancer cells. Int J Oncol 2013; 42: 2069-77. doi: 10.3892/ ijo.2013.1909

62. Kim TW, Lee SY, Kim M, Cheon C, Ko SG. Kaempferol induces autophagic cell death via IRE1-JNK-CHOP pathway and inhibition of G9a in gastric cancer cells. Cell Death Dis 2018; 9: 875. doi: 10.1038/s41419-018-0930-1

63. Ci Y, Zhang Y, Liu Y, Lu S, Cao J, Li H, et al. Myricetin suppresses breast cancer metastasis through down-regulating the activity of matrix metalloproteinase (MMP)-2/9. Phytother Res 2018; 32: 1373-81. doi: 10.1002/ptr.6071

64. Devi KP, Rajavel T, Habtemariam S, Nabavi SF, Nabavi SM. Molecular mechanisms underlying anticancer effects of myricetin. Life Sci 2015; 142: 19-25. doi: 10.1016/j.lfs.2015.10.004

65. Ghassemi-Rad J, Maleki M, Knickle AF, Hoskin DW. Myricetin-induced oxidative stress suppresses murine $\mathrm{T}$ lymphocyte activation. Cell Biol Int 2018; 42: 1069-75. doi: 10.1002/ cbin. 10977

66. Arts IC, van De Putte B, Hollman PC. Catechin contents of foods commonly consumed in The Netherlands. 2. Tea, wine, fruit juices, and chocolate milk. J Agric Food Chem 2000; 48: 1752-7. doi: 10.1021/jf000026+

67. Al-Dashti YA, Holt RR, Stebbins CL, Keen CL, Hackman RM. Dietary flavanols: a review of select effects on vascular function, blood pressure, and exercise performance. J Am Coll Nutr 2018; 37: 553-67. doi: 10.1080/07315724.2018.1451788

68. Rogovskii VS, Popov SV, Sturov NV, Shimanovskii NL. The possibility of preventive and therapeutic use of green tea catechins in prostate cancer. Anticancer Agents Med Chem 2019; 19: 1223-31. doi: 10.2174/1871520619666190404153058

69. Yang CS, Wang H. Cancer preventive activities of tea catechins. Molecules 2016; 21: 1679. doi: 10.3390/molecules21121679

70. Bimonte S, Cascella M, Leongito M, Palaia R, Caliendo D, Izzo F, et al. An overview of pre-clinical studies on the effects of (-)-epigallocatechin-3-gallate, a catechin found in green tea, in treatment of pancreatic cancer. Recenti Prog Med 2017; 108: 282-7. doi: 10.1701/2715.27715

71. Shimizu M, Shirakami Y, Sakai H, Adachi S, Hata K, Hirose Y, et al. (-)-Epigallocatechin gallate suppresses azoxymethane-induced colonic premalignant lesions in male C57BL/KsJ-db/db mice. Cancer Prevent Res 2008; 1: 298-304. doi: 10.1158/19406207.CAPR-08-0045

72. Varela-Castillo O, Cordero P, Gutierrez-Iglesias G, Palma I, Rubio-Gayosso I, Meaney E, et al. Characterization of the cytotoxic effects of the combination of cisplatin and flavanol (-)-epicatechin on human lung cancer cell line A549. An isobolographic approach. Exp Oncol 2018; 40: 19-23. doi: 10.31768/2312-8852.2018.40(1):19-23 
73. Lee JS, Kang SU, Hwang HS, Pyun JH, Choung YH, Kim CH. Epicatechin protects the auditory organ by attenuating cisplatin-induced ototoxicity through inhibition of ERK. Toxicol Lett 2010; 199: 308-16. doi: 10.1016/j.toxlet.2010.09.013

74. Granado-Serrano AB, Martin MA, Haegeman G, Goya L, Bravo L, Ramos S. Epicatechin induces NF-kappaB, activator protein-1 (AP-1) and nuclear transcription factor erythroid 2p45-related factor-2 (Nrf2) via phosphatidylinositol-3-kinase/ protein kinase $\mathrm{B}$ (PI3K/AKT) and extracellular regulated kinase (ERK) signalling in HepG2 cells. Br J Nutr 2010; 103: 168-79. doi: 10.1017/S0007114509991747

75. Yamazaki KG, Andreyev AY, Ortiz-Vilchis P, Petrosyan S, Divakaruni AS, Wiley SE, et al. Intravenous (-)-epicatechin reduces myocardial ischemic injury by protecting mitochondrial function. Int J Cardiol 2014; 175: 297-306. doi: 10.1016/j. ijcard.2014.05.009

76. Godsey J, Grundmann O. Review of various herbal supplements as complementary treatments for oral cancer. J Diet Suppl 2016; 13: 538-50. doi: 10.3109/19390211.2015.1122693

77. Pae $\mathrm{M}, \mathrm{Wu} \mathrm{D}$. Immunomodulating effects of epigallocatechin-3-gallate from green tea: mechanisms and applications. Food Funct 2013; 4: 1287-303. doi: 10.1039/c3fo60076a

78. Gollucke APB, Aguiar O, Barbisan LF, Ribeiro DA. Use of grape polyphenols against carcinogenesis: putative molecular mechanisms of action using in vitro and in vivo test systems. J Med Food 2013; 16: 199-205. doi: 10.1089/jmf.2012.0170

79. Wang Y, Stevens VL, Shah R, Peterson JJ, Dwyer JT, Gapstur SM, et al. Dietary flavonoid and proanthocyanidin intakes and prostate cancer risk in a prospective cohort of US men. Am J Epidemiol 2014; 179: 974-86. doi: 10.1093/aje/kwu006

80. King M, Chatelain K, Farris D, Jensen D, Pickup J, Swapp A, et al. Oral squamous cell carcinoma proliferative phenotype is modulated by proanthocyanidins: a potential prevention and treatment alternative for oral cancer. BMC Complement Altern Med 2007; 7: 22. doi: 10.1186/1472-6882-7-22

81. Engelbrecht AM, Mattheyse M, Ellis B, Loos B, Thomas M, Smith R, et al. Proanthocyanidin from grape seeds inactivates the PI3-kinase/PKB pathway and induces apoptosis in a colon cancer cell line. Cancer Lett 2007; 258: 144-53. doi: 10.1016/j. canlet.2007.08.020

82. Park SY, Lee YH, Choi KC, Seong AR, Choi HK, Lee OH, et al. Grape seed extract regulates androgen receptor-mediated transcription in prostate cancer cells through potent anti-histone acetyltransferase activity. J Med Food 2011; 14: 9-16. doi: 10.1089/jmf.2010.1264

83. Smeriglio A, Barreca D, Bellocco E, Trombetta D. Proanthocyanidins and hydrolysable tannins: occurrence, dietary intake and pharmacological effects. Br J Pharmacol 2017; 174: 1244-62. doi: 10.1111/bph.13630

84. Sieniawska E. Activities of tannins - from in vitro studies to clinical trials. Nat Prod Commun 2015; 10: 1877-84. doi: 10.1177/1934578X1501001118

85. Kong JM, Chia LS, Goh NK, Chia TF, Brouillard R. Analysis and biological activities of anthocyanins. Phytochemistry 2003; 64: 923-33. doi: 10.1016/s0031-9422(03)00438-2

86. Jennings A, Welch AA, Fairweather-Tait SJ, Kay C, Minihane AM, Chowienczyk P, et al. Higher anthocyanin intake is associated with lower arterial stiffness and central blood pressure in women. Am J Clin Nutr 2012; 96: 781-8. doi: 10.3945/ ajcn.112.042036

87. Zamora-Ros R, Agudo A, Lujan-Barroso L, Romieu I, Ferrari $\mathrm{P}, \mathrm{Knaze} \mathrm{V}$, et al. Dietary flavonoid and lignan intake and gastric adenocarcinoma risk in the European Prospective
Investigation into Cancer and Nutrition (EPIC) study. Am J Clin Nutr 2012; 96: 1398-408. doi: 10.3945/ajen.112.037358

88. Li D, Wang P, Luo Y, Zhao M, Chen F. Health benefits of anthocyanins and molecular mechanisms: update from recent decade. Crit Rev Food Sci Nutr 2017; 57: 1729-41. doi: 10.1080/10408398.2015.1030064

89. Lin BW, Gong CC, Song HF, Cui YY. Effects of anthocyanins on the prevention and treatment of cancer. Br J Pharmacol 2017; 174: 1226-43. doi: 10.1111/bph.13627

90. Liang L, Liu X, He J, Shao Y, Liu J, Wang Z, et al. Cyanidin-3-glucoside induces mesenchymal to epithelial transition via activating Sirt1 expression in triple negative breast cancer cells. Biochimie 2019; 162: 107-15. doi: 10.1016/j.biochi.2019.03.004

91. Cho E, Chung EY, Jang HY, Hong OY, Chae HS, Jeong YJ, et al. Anti-cancer effect of cyanidin-3-glucoside from mulberry via caspase-3 cleavage and DNA fragmentation in vitro and in vivo. Anticancer Agents Med Chem 2017; 17: 1519-25. doi: 10.2174/1871520617666170327152026

92. Baster Z, Li L, Kukkurainen S, Chen J, Pentikainen O, Gyorffy $\mathrm{B}$, et al. Cyanidin-3-glucoside binds to talin and modulates colon cancer cell adhesions and 3D growth. FASEB J 2020; 34: 2227-37. doi: 10.1096/fj.201900945R

93. Liu X, Zhang D, Hao Y, Liu Q, Wu Y, Liu X, et al. Cyanidin curtails renal cell carcinoma tumorigenesis. Cell Physiol Biochem 2018; 46: 2517-31. doi: 10.1159/000489658

94. Wang H, Li S, Zhang G, Wu H, Chang X. Potential therapeutic effects of cyanidin-3-O-glucoside on rheumatoid arthritis by relieving inhibition of CD38+ NK cells on Treg cell differentiation. Arthritis Res Ther 2019; 21: 220. doi: 10.1186/ s13075-019-2001-0

95. Huang CC, Hung CH, Hung TW, Lin YC, Wang CJ, Kao SH. Dietary delphinidin inhibits human colorectal cancer metastasis associating with upregulation of miR-204-3p and suppression of the integrin/FAK axis. Sci Rep 2019; 9: 18954. doi: 10.1038/s41598-019-55505-Z

96. Lim WC, Kim H, Kim YJ, Park SH, Song JH, Lee KH, et al. Delphinidin inhibits BDNF-induced migration and invasion in SKOV3 ovarian cancer cells. Bioorg Med Chem Lett 2017; 27: 5337-43. doi: 10.1016/j.bmcl.2017.09.024

97. Lim W, Song G. Inhibitory effects of delphinidin on the proliferation of ovarian cancer cells via PI3K/AKT and ERK 1/2 MAPK signal transduction. Oncol Lett 2017; 14: 810-8. doi: 10.3892/ol.2017.6232

98. Chen J, Zhou J, Li F, Zhu Y, Zhang W, Yu X. Delphinidin induces autophagy in HER-2+ breast cancer cells via inhibition of AKT/mTOR pathway. Zhong Nan Da Xue Xue Bao Yi Xue Ban 2017; 42: 264-70. doi: 10.11817/j. issn.1672-7347.2017.03.005

99. Jeong MH, Ko H, Jeon H, Sung GJ, Park SY, Jun WJ, et al. Delphinidin induces apoptosis via cleaved HDAC3-mediated p53 acetylation and oligomerization in prostate cancer cells. Oncotarget 2016; 7: 56767-80. doi: 10.18632/oncotarget.10790

100. Ho ML, Chen PN, Chu SC, Kuo DY, Kuo WH, Chen JY, et al. Peonidin 3-glucoside inhibits lung cancer metastasis by downregulation of proteinases activities and MAPK pathway. Nutr Cancer 2010; 62: 505-16. doi: 10.1080/01635580903441261

101. Chen PN, Chu SC, Chiou HL, Chiang CL, Yang SF, Hsieh YS. Cyanidin 3-glucoside and peonidin 3-glucoside inhibit tumor cell growth and induce apoptosis in vitro and suppress tumor growth in vivo. Nutr Cancer 2005; 53: 232-43. doi: 10.1207/ s15327914nc5302_12

102. Liu W, Xu J, Wu S, Liu Y, Yu X, Chen J, et al. Selective anti-proliferation of HER2-positive breast cancer cells by 
anthocyanins identified by high-throughput screening. PLoS One 2013; 8: e81586. doi: 10.1371/journal.pone.0081586

103. Zhang Y, Vareed SK, Nair MG. Human tumor cell growth inhibition by nontoxic anthocyanidins, the pigments in fruits and vegetables. Life Sci 2005; 76: 1465-72. doi: 10.1016/j. lfs. 2004.08 .025

104. Wang Y, Lin J, Tian J, Si X, Jiao X, Zhang W, et al. Blueberry malvidin-3-galactoside suppresses hepatocellular carcinoma by regulating apoptosis, proliferation, and metastasis pathways in vivo and in vitro. J Agric Food Chem 2019; 67: 625-36. doi: 10.1021/acs.jafc. 8 b06209

105. Wang G, Fu XL, Wang JJ, Guan R, Sun Y, Tony To SS. Inhibition of glycolytic metabolism in glioblastoma cells by Pt3glc combinated with PI3K inhibitor via SIRT3-mediated mitochondrial and PI3K/Akt-MAPK pathway. J Cell Physiol 2019; 234: 5888-903. doi: 10.1002/jcp.26474

106. Pham-Huy LA, He H, Pham-Huy C. Free radicals, antioxidants in disease and health. Int J Biomed Sci 2008; 4: 89-96.

107. Jeandet P, Bessis R, Maume BF, Meunier P, Peyron D, Trollat $\mathrm{P}$. Effect of enological practices on the resveratrol isomer content of wine. J Agric Food Chem 1995; 43: 316-9. doi: 10.1021/ Jf00050a010

108. Maruyama H, Kawakami F, Lwin TT, Imai M, Shamsa F. Biochemical characterization of ferulic acid and caffeic acid which effectively inhibit melanin synthesis via different mechanisms in B16 melanoma cells. Biol Pharm Bull 2018; 41: 806-10. doi: 10.1248/bpb.b17-00892

109. Rosendahl AH, Perks CM, Zeng L, Markkula A, Simonsson $\mathrm{M}$, Rose $\mathrm{C}$, et al. Caffeine and caffeic acid inhibit growth and modify estrogen receptor and insulin-like growth factor I receptor levels in human breast cancer. Clin Cancer Res 2015; 21: 1877-87. doi: 10.1158/1078-0432.CCR-14-1748

110. Tyszka-Czochara M, Bukowska-Strakova K, Kocemba-Pilarczyk KA, Majka M. Caffeic acid targets AMPK signaling and regulates tricarboxylic acid cycle anaplerosis while metformin downregulates HIF-1alpha-induced glycolytic enzymes in human cervical squamous cell carcinoma lines. Nutrients 2018; 10: 841. doi: 10.3390/nu10070841

111. Zhang X, Lin D, Jiang R, Li H, Wan J, Li H. Ferulic acid exerts antitumor activity and inhibits metastasis in breast cancer cells by regulating epithelial to mesenchymal transition. Oncol Rep 2016; 36: 271-8. doi: 10.3892/or.2016.4804

112. Wang T, Gong X, Jiang R, Li H, Du W, Kuang G. Ferulic acid inhibits proliferation and promotes apoptosis via blockage of PI3K/Akt pathway in osteosarcoma cell. Am J Transl Res 2016; 8: 968-80. doi:

113. Gao JH, Yu H, Guo WK, Kong Y, Gu LN, Li Q, et al. The anticancer effects of ferulic acid is associated with induction of cell cycle arrest and autophagy in cervical cancer cells. Cancer Cell Int 2018; 18: 102. doi: 10.1186/S12935-018-0595-Y

114. Kawabata K, Yamamoto T, Hara A, Shimizu M, Yamada Y, Matsunaga K, et al. Modifying effects of ferulic acid on azoxymethane-induced colon carcinogenesis in F344 rats. Cancer Lett 2000; 157: 15-21. doi: 10.1016/s0304-3835(00)00461-4

115. Lukitasari M, Nugroho DA, Widodo N. Chlorogenic acid: the conceivable chemosensitizer leading to cancer growth suppression. J Evid Based Integr Med 2018; 23: 2515690X18789628. doi: $10.1177 / 2515690 X 18789628$

116. Wang X, Liu J, Xie Z, Rao J, Xu G, Huang K, et al. Chlorogenic acid inhibits proliferation and induces apoptosis in A498 human kidney cancer cells via inactivating PI3K/Akt/mTOR signalling pathway. J Pharm Pharmacol 2019; 71: 1100-9. doi: 10.1111/jphp. 13095
117. Verma S, Singh A, Mishra A. Gallic acid: molecular rival of cancer. Environ Toxicol Pharmacol 2013; 35: 473-85. doi: 10.1016/j.etap.2013.02.011

118. Pang JS, Yen JH, Wu HT, Huang ST. Gallic acid inhibited matrix invasion and AP-1/ETS-1-mediated MMP-1 transcription in human nasopharyngeal carcinoma cells. Int J Mol Sci 2017; 18: 1354. doi: 10.3390/ijms 18071354

119. Gong J, Zhou S, Yang S. Vanillic acid suppresses HIF-1 alpha expression via inhibition of mTOR/p70S6K/4E-BP1 and Raf/ MEK/ERK pathways in human colon cancer HCT116 cells. Int J Mol Sci 2019; 20: 465. doi: 10.3390/ijms20030465

120. Pei K, Ou J, Huang J, Ou S. p-Coumaric acid and its conjugates: dietary sources, pharmacokinetic properties and biological activities. J Sci Food Agric 2016; 96: 2952-62. doi: 10.1002/ jsfa.7578

121. Quideau S, Deffieux D, Douat-Casassus C, Pouysegu L. Plant polyphenols: chemical properties, biological activities, and synthesis. Angew Chem Int Ed Engl 2011; 50: 586-621. doi: 10.1002/anie. 201000044

122. Landete JM. Ellagitannins, ellagic acid and their derived metabolites: a review about source, metabolism, functions and health. Food Res Int 2011; 44: 1150-60. doi: 10.1016/j. foodres.2011.04.027

123. Duan J, Zhan JC, Wang GZ, Zhao XC, Huang WD, Zhou GB. The red wine component ellagic acid induces autophagy and exhibits anti-lung cancer activity in vitro and in vivo. J Cell Mol Med 2019; 23: 143-54. doi: 10.1111/jcmm.13899

124. Ismail T, Calcabrini C, Diaz AR, Fimognari C, Turrini E, Catanzaro E, et al. Ellagitannins in cancer chemoprevention and therapy. Toxins 2016; 8: 151. doi: 10.3390/toxins 8050151

125. Heber D. Multitargeted therapy of cancer by ellagitannins. Cancer Lett 2008; 269: 262-8. doi: 10.1016/j. canlet.2008.03.043

126. Adams LS, Seeram NP, Aggarwal BB, Takada Y, Sand D, Heber D. Pomegranate juice, total pomegranate ellagitannins, and punicalagin suppress inflammatory cell signaling in colon cancer cells. J Agric Food Chem 2006; 54: 980-5. doi: 10.1021/ jf052005r

127. Kasimsetty SG, Bialonska D, Reddy MK, Ma G, Khan SI, Ferreira D. Colon cancer chemopreventive activities of pomegranate ellagitannins and urolithins. J Agric Food Chem 2010; 58: 2180-7. doi: 10.1021/jf903762h

128. Kwon HY, Kim JH, Kim B, Srivastava SK, Kim SH. Regulation of SIRT1/AMPK axis is critically involved in gallotannin-induced senescence and impaired autophagy leading to cell death in hepatocellular carcinoma cells. Archiv Toxicol 2018; 92: 241-57. doi: 10.1007/s00204-017-2021-y

129. Nemec MJ, Kim H, Marciante AB, Barnes RC, Talcott ST, Mertens-Talcott SU. Pyrogallol, an absorbable microbial gallotannins-metabolite and mango polyphenols (Mangifera Indica L.) suppress breast cancer ductal carcinoma in situ proliferation in vitro. Food Funct 2016; 7: 3825-33. doi: 10.1039/ c6fo00636a

130. RomeroPerez AI, LamuelaRaventos RM, Waterhouse AL, delaTorreBoronat MC. Levels of cis- and trans-resveratrol and their glucosides in white and rose Vitis vinifera wines from Spain. J Agric Food Chem 1996; 44: 2124-8. doi: 10.1021/ Jf9507654

131. Lamuelaraventos RM, Romeroperez AI, Waterhouse AL, Delatorreboronat MC. Direct Hplc analysis of Cis-resveratrol and trans-resveratrol and piceid isomers in Spanish red vitis-vinifera wines. J Agric Food Chem 1995; 43: 281-3. doi: 10.1021/ Jf00050a003 
132. Rauf A, Imran M, Butt MS, Nadeem M, Peters DG, Mubarak MS. Resveratrol as an anti-cancer agent: a review. Crit Rev Food Sci Nutr 2018; 58: 1428-47. doi: 10.1080/10408398.2016.1263597

133. Leonard SS, Xia C, Jiang BH, Stinefelt B, Klandorf H, Harris GK, et al. Resveratrol scavenges reactive oxygen species and effects radical-induced cellular responses. Biochem Biophys Res Commun 2003; 309: 1017-26. doi: 10.1016/j.bbrc.2003.08.105

134. Kode A, Rajendrasozhan S, Caito S, Yang SR, Megson IL, Rahman I. Resveratrol induces glutathione synthesis by activation of Nrf2 and protects against cigarette smoke-mediated oxidative stress in human lung epithelial cells. Am J Physiol Lung Cell Mol Physiol 2008; 294: L478-88. doi: 10.1152/ ajplung.00361.2007

135. Okada H, Mak TW. Pathways of apoptotic and non-apoptotic death in tumour cells. Nat Rev Cancer 2004; 4: 592-603. doi: $10.1038 / \mathrm{nrc} 1412$

136. Liao PC, Ng LT, Lin LT, Richardson CD, Wang GH, Lin CC. Resveratrol arrests cell cycle and induces apoptosis in human hepatocellular carcinoma Huh-7 cells. J Med Food 2010; 13: 1415-23. doi: 10.1089/jmf.2010.1126

137. Aziz MH, Nihal M, Fu VX, Jarrard DF, Ahmad N. Resveratrol-caused apoptosis of human prostate carcinoma LNCaP cells is mediated via modulation of phosphatidylinositol 3'-kinase/Akt pathway and Bcl-2 family proteins. Mol Cancer Ther 2006; 5: 1335-41. doi: 10.1158/1535-7163.MCT-05-0526

138. Benitez DA, Hermoso MA, Pozo-Guisado E, Fernandez-Salguero PM, Castellon EA. Regulation of cell survival by resveratrol involves inhibition of NF kappa B-regulated gene expression in prostate cancer cells. Prostate 2009; 69: 1045-54. doi: 10.1002/pros.20953

139. Colin D, Limagne E, Jeanningros S, Jacquel A, Lizard G, Athias A, et al. Endocytosis of resveratrol via lipid rafts and activation of downstream signaling pathways in cancer cells. Cancer Prevent Res 2011; 4: 1095-106. doi: 10.1158/1940-6207.CAPR-10-0274

140. Su JL, Yang CY, Zhao M, Kuo ML, Yen ML. Forkhead proteins are critical for bone morphogenetic protein-2 regulation and anti-tumor activity of resveratrol. J Biol Chem 2007; 282: 19385-98. doi: 10.1074/jbc.M702452200

141. Kim YA, Lee WH, Choi TH, Rhee SH, Park KY, Choi YH Involvement of p21WAF1/CIP1, pRB, Bax and NF-kappaB in induction of growth arrest and apoptosis by resveratrol in human lung carcinoma A549 cells. Int J Oncol 2003; 23: 1143-9. doi: 10.1136/bjo.2007.132290

142. Whyte L, Huang YY, Torres K, Mehta RG. Molecular mechanisms of resveratrol action in lung cancer cells using dual protein and microarray analyses. Cancer Res 2007; 67: 12007-17. doi: 10.1158/0008-5472.CAN-07-2464

143. Ahmad N, Adhami VM, Afaq F, Feyes DK, Mukhtar H. Resveratrol causes WAF-1/p21-mediated G(1)-phase arrest of cell cycle and induction of apoptosis in human epidermoid carcinoma A431 cells. Clin Cancer Res 2001; 7: 1466-73.
144. Ko JH, Sethi G, Um JY, Shanmugam MK, Arfuso F, Kumar AP, et al. The role of resveratrol in cancer therapy. Int J Mol Sci 2017; 18: 2589. doi: 10.3390/ijms18122589

145. Limagne E, Thibaudin M, Euvrard R, Berger H, Chalons P, Vegan F, et al. Sirtuin-1 activation controls tumor growth by impeding Th17 differentiation via STAT3 deacetylation. Cell Rep 2017; 19: 746-59. doi: 10.1016/j.celrep.2017.04.004

146. Vergara D, Valente CM, Tinelli A, Siciliano C, Lorusso $\mathrm{V}$, Acierno R, et al. Resveratrol inhibits the epidermal growth factor-induced epithelial mesenchymal transition in MCF-7 cells. Cancer Lett 2011; 310: 1-8. doi: 10.1016/j. canlet.2011.04.009

147. Tosolini M, Kirilovsky A, Mlecnik B, Fredriksen T, Mauger $\mathrm{S}$, Bindea $\mathrm{G}$, et al. Clinical impact of different classes of infiltrating $\mathrm{T}$ cytotoxic and helper cells (Th1, th2, treg, th17) in patients with colorectal cancer. Cancer Res 2011; 71: 1263-71. doi: 10.1158/0008-5472.CAN-10-2907

148. Delmas D, Limagne E, Ghiringhelli F, Aires V. Immune Th17 lymphocytes play a critical role in the multiple beneficial properties of resveratrol. Food Chem Toxicol 2020; 137: 111091. doi: 10.1016/j.fct.2019.111091

149. Zhang Y, Yang S, Yang Y, Liu T. Resveratrol induces immunogenic cell death of human and murine ovarian carcinoma cells. Infect Agents Cancer 2019; 14: 27. doi: 10.1186/ s13027-019-0247-4

150. Yang Y, Paik JH, Cho D, Cho JA, Kim CW. Resveratrol induces the suppression of tumor-derived CD4+CD25+ regulatory $\mathrm{T}$ cells. Int Immunopharmacol 2008; 8: 542-7. doi: 10.1016/j.intimp.2007.12.006

151. Verdura S, Cuyas E, Cortada E, Brunet J, Lopez-Bonet E, Martin-Castillo B, et al. Resveratrol targets PD-L1 glycosylation and dimerization to enhance antitumor T-cell immunity. Aging 2020; 12: 8-34. doi: 10.18632/aging. 102646

152. Valentovic MA. Evaluation of resveratrol in cancer patients and experimental models. Adv Cancer Res 2018; 137: 171-88. doi: 10.1016/bs.acr.2017.11.006

\author{
*Yulin Fang \\ College of Enology \\ Northwest A\&F University \\ Yangling, China \\ Email: fangyulin@nwsuaf.edu.cn
}

\section{*Guangbiao Zhou}

State Key Laboratory of Molecular Oncology

National Cancer Center/National Clinical Research Center for

Cancer/Cancer Hospital Chinese Academy of Medical Sciences and Peking Union Medical College

Beijing, China

Email: gbzhou@cicams.ac.cn 